Огляди літератури, оригінальні дослідження, погляд на проблему

УДК 616.37-002-036.12+616.37-008]-072.2-073.452.19

DOI 10.11603/1811-2471.2017.v1.i3.8167

\title{
ДІАГНОСТИКА ХРОНІЧНОГО ПАНКРЕАТИТУ І ФУНКЦІОНАЛЬНИХ ПОРУШЕНЬ ПІДШЛУНКОВОЇ ЗАЛОЗИ ПРИ СУПУТНІХ ЗАХВОРЮВАННЯХ ДВАНАДЦЯТИПАЛОї КИШКИ
}

\author{
๑Л. П. Кузнецова, Ю. І. Решетілов, С. М. Дмітрієва, Т. В. Богослав, Н. М. Проценко, \\ О. Ю. Васильченко, М. В. Бондарь, А. А. Партеса
}

ДЗ «Запорізька медична академія післядипломної освіти МОЗ України»

Запорізький державний медичний університет

РЕзЮМЕ. В роботі представлені результати дослідження тонічної і функціональної активності підшлункової залози (ПЗ) в міжтравний період (МТП) у хворих на хронічний панкреатит (ХП) при супутній патології дванадцятипалої кишки (ДПК).

Мета - визначити стан підшлункової залози в МТП у хворих на ХП при захворюваннях ДПК з використанням методу поліметрії і ультрасонографії в режимі моніторингу.

Результати. Дослідження за вказаною методикою показало, що розміри і ехоструктура Пз непостійні як у хворих, так і у здорових осіб. Вони змінюються залежно від фаз МТМ ДПК. У здорових залоза буває найбільшою в ІІ фазу нерегулярної моторики, що триває $(56,8 \pm 4,1)$ хвилин, в III фазу - ритмічних скорочень, що триває $(7,6 \pm 0,8)$ хвилин, вона буває найменшою, а ехоструктура її підсилюється. Коливання розмірів ПЗ при цьому складають: в ділянці

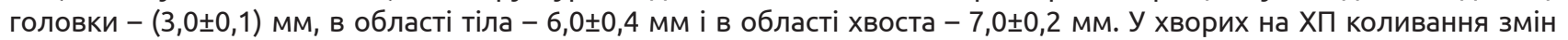
розмірів і ехоструктури залози залежать від тяжкості та тривалості основного захворювання, а також від типу супутньої дискінезії ДПК. При гіпомоторній дискінезії, характерній для АД і ХПДП, вираженої динаміки в змінах розмірів та ехоструктури залози ми не спостерігали $(P<0,05)$. У хворих на ХД з гіпермоторним типом дискінезії ДПК виявлено зменшення розмірів ПЗ і підсилення їі ехоструктури в II і III фази моторики (Р<0,05). У хворих на XП, осо6ливо при тяжкому перебігу захворювання і тривалості захворювання більше 15 років, коливання змін розмірів і ехоструктури ПЗ за фазами МТМ не виявилось $(\mathrm{P}<0,05)$. Дані ультрасонографії ПЗ у динаміці відповідали формі й стадії ХП.

Використання в дослідженні зазначеної методики дозволило виявити ХП лише у 29 \% обстежених, підтвердивши його наявність клінічними, інструментальними і лабораторними методами; у інших 71,0 \% обстежених, які в поліклініці при направленні в клініку класифікувалися як хворі на “хронічний панкреатит», зміни з боку ПЗ розглядати як функціональні, вторинні, клінічно відповідні гіпо- або гіпермоторній дискінезії ДПк.

Висновки. 1. Показники фазної тонічної активності ПЗ в МТП є важливими критеріями в диференціальній діагностиці органічних уражень ПЗ, зокрема при ХП, і функціонального її стану, відповідно фазам моторики і типу дискінезії ДПК.

2. Для одержання об'єктивної інформації про стан підшлункової залози при ультрасонографії слід враховувати тривалість МТП (в середньому 90 хвилин), фазні зміни розмірів і ехоструктури П3, та проводити дослідження тричі з інтервалом не менше 30 хвилин.

КлючовІ СлОВА: підшлункова залоза; хронічний панкреатит; дванадцятипала кишка; фази моторики; міжтравний період.

Вступ. Неухильний ріст захворювання серед людей активних вікових груп, прогресуючий перебіг, часті рецидиви з тривалою тимчасовою, а іноді й стійкою втратою працездатності роблять ХП проблемою не тільки медичною, а й соціальною, що привертає увагу багатьох фахівців [1-7]. Актуальність дослідження проблеми ХП визначається надзвичайно важливою роллю, яку ПЗ виконує в організмі. Вона $\epsilon$ життєво важливим органом, одним із центральних у системі травлення, що бере участь в загальних метаболічних процесах в організмі та разом з тим, $\epsilon$ носієм ендокринних функцій $[1,7]$.

Найактуальнішою проблемою $\epsilon$ удосконалення методів діагностики хронічного панкреатиту $[3,4,6]$, оскільки високою залишається як гіпер-, так і гіподіагностика його. Діагноз ХП не завжди встановлюють там, де він $\epsilon$, і навпаки, встановлю- ють там, де його немає. У клініці захворювання провідним часто $\epsilon$ стійкий больовий синдром в епігастральній ділянці, що знижує якість життя хворого і викликає безпорадність у лікаря.

ДПК знаходиться анатомічно, морфологічно і функціонально у тісному взаємозв'язку з оточуючими органами травлення, тому порушення моторно-евакуаторної функції кишки може призвести не тільки до розладу в їх функціональному синергізмі, а й до виникнення органічних уражень.

У вітчизняній і зарубіжній літературі майже немає робіт, що вивчають взаємозв'язки дисфазної моторики і дисфазного тиску ДПК з функціональним станом і активністю ПЗ в МТП, в тому числі й у хворих на ХП.

Для діагностики ХП використовують різні методи: клінічні, лабораторні, інструментальні (термометрія, ультрасонографія, агіографія, комп'ю- 
Огляди літератури, оригінальні дослідження, погляд на проблему

терна і магнітнорезонансна томографія), але основним діагностичним інструментальним методом на сьогоднішний день залишається ультразвукове дослідження (УЗД), яке дозволяє одержати уявлення про розміри, форму, морфологічну структуру ПЗ. Але інтерпретація одержаних результатів нерідко буває відносною, що часто призводить до гіпердіагностики ХП та призначення необґрунтованого лікування, в тому числі й хірургічного. На наш погляд, це обумовлено тим, що УЗД ПЗ проводиться без урахування ії̈ фазної тонічної активності в МТП. У зв'язку з цим виникає потреба у розробці нових і модифікації відомих методів для судження про функціональний стан П3, взаємозв'язок вторинних її уражень з патологією ДПК та активну діяльність в МТП. Вирішення цієї проблеми дозволяє покращити ранню діагностику вторинних уражень ПЗ при захворюваннях ДПК, що проходять з порушенням моторики і інтрадуоденального тиску; проводити диференційну діагностику органічних і функціональних уражень ПЗ; зменшити гіпердіагностику ХП; своєчасно призначати та використовувати патогенетично зумовлене лікування; зменшити непрацездатність хворих активних вікових груп та покращити якість їх життя.

Мета дослідження - вивчити стан підшлункової залози в міжтравний період у хворих на хронічний панкреатит при захворюваннях дванадцятипалої кишки.

Матеріал і методи дослідження. Обстежено 126 хворих на ХП віком від 18 до 70 років; жінок було 78 (60,0 \%), чоловіків - 48 (40,0\%). Контрольну групу склали 20 здорових осіб, зіставних за віком і статевою належністю. Розподіл хворих за віком показав, що різниці в захворюваності на ХП серед жінок і чоловіків статистикою не виявлено як у віковій групі до 20 років (відповідно 5,2 \% і 5,5 \%), так і у віці 61-70 років (відповідно $4,9 \%$ і 4,5 \% ). Більша частина хворих як серед жінок, так і серед чоловіків була у віці 31-40 років (38,9 \% і 37,5 \%) і у віці 41-50 (26,4 \% і 37,5 \%). При аналізі віку хворих, в якому почалося захворювання, виявлено, що у віці 21-30 років чоловіків захворіло $(36,5 \pm 5,5) \%$ жінок - $(29,3 \pm 4,7) \%$, а у віці 31-40 років цей показник виявився вищим серед

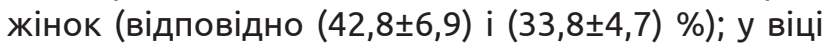
$41-50$ років жінок захворіло $(10,7 \pm 3,2) \%$, чоловіків - $(13,4 \pm 3,8)$, а у віці 51-60 - відповідно $(9,6 \pm \%$ і $(4,9 \pm 1,1) \%$. У віці 61-70 років вперше виявленого захворювання на ХП не спостерігали.

При з'ясуванні можливих етіологічних факторів виникнення ХП 9,0 \% обстежених назвали перенесений в анамнезі гострий панкреатит; 41,4%порушення режиму і характеру харчування; 39,2 \% - зловживання гострими стравами, кавою; травма живота - 4,4 \%. Назвати причину не змогли 6,0 \% хворих. Серед обстежених 92,0\% хворих чоловіків і 89,0 \% жінок виявилися курцями; алкоголь вживали 87,0 \% хворих.

Із супутніх захворювань шлунково-кишкового тракту (ШКТ) найчастіше виявляли патологію ДПК (69,4\%), причому ХД та ХПДП виявлені в 47,3 \% випадків, виразкова хвороба (ВХ) ДПК (ВХДПК) - в 17,9 \%, шлунка - в 4,2 \%, хронічний безкам'яний холецистит (ХБХ) і дискінезії ЖВШ у 20,4 \%, жовчнокам'яна хвороба (ЖКХ) - у 10,2 \% обстежених; із інших патологій виявили захворювання суглобів, а саме остеоартроз колінних суглобів, яким страждали 39,9 \% обстежуваних хворих, що перебувають на диспансерному обліку у сімейного лікаря за місцем проживання і потребують постійного прийому знеболювальних, протизапальних препаратів.

Діагноз ХП встановлювали на підставі загальновизнаних ознак даної патології, а також відповідно до стандартизованих протоколів діагностики та лікування (за загальноприйнятою в Україні класифікацією).

Гастродуоденальну моторику і внутрішньопорожнинний тиск проксимальних відділів ШКТ вивчали за допомогою універсального багатоканального зонда, запропонованого професором Решетіловим Ю. І. (винахід № 423151513/14/042931) 3 одночасною реєстрацією інформації на паперовій стрічці самописця (поліграф «Салют»), і рН в ДПК і антральному відділі шлунка (АВШ) - на екрані монітора. При аналізі результатів дослідження враховували: базальний внутрішньопорожнинний тиск (в мм вод. стовпчика); загальну тривалість циклу МТМ (в Хв), тривалість I фази - фази спокою, II - нерегулярних скорочень, III - ритмічної моторики (в хв); амплітуду скорочень ДПК і шлунка (в мм вод. стовпчика); частоту скорочень ДПК і шлунка у кожній фазі МТМ.

Міжтравну тонічну активність (МТА) ПЗ і стан протокової системи визначали за допомогою УЗД в режимі моніторингу (тричі через кожні 30 хвилин) на апараті «Anakogic scientific» моделі «ASU-01 C». Реєстрували: положення, форму, розміри і ехоструктуру залози по фазах МТМ ДПК; ФЕГДС здійснювали апаратом фірми «Olimpus» GLF-K2 за загальноприйнятою методикою. Гастроскопічну картину з боку СО ДПК і АВШ оцінювали за параметрами як: незмінну СО; поверхневий гастрит і дуоденіт без ерозій або з ерозіями; атрофічний антральний гастрит (ААГ) і дуоденіт Для вивчення характеру структурних змін слизової оболонки (СО) ДПК і АВШ, взаємозв'язку їх з розвитком функціональних порушень (ФП) ПЗ, 49 хворим проведена прицільна біопсія. При гістологічному дослідженні біоптатів ураховували розміри і величину ворсин, 
Огляди літератури, оригінальні дослідження, погляд на проблему

глибину крипт, ступінь запальної інфільтрації власної пластини. Оцінку стану СО проводили згідно з критеріями Л. І. Аруїна (1967).

Всім обстеженим в динаміці проводили копрологічне дослідження в балах на виявлення стеатореї, креатореї і амілореї, які можуть свідчити про зовнішньосекреторну недостатність ПЗ. Біохімічні дослідження крові, загальноклінічні аналізи крові і сечі проводили згідно з сучасними методиками.

Комп'ютерну обробку отриманих даних проводили за допомогою програми Microsoft Excel.

Результати й обговорення. Клінічна характеристика обстежуваних включала найважливіші анамнестичні дані, дані об'єктивного огляду, результати інструментальних, рентгенологічних, ультрасонографічного і лабораторних досліджень. Незалежно від етіологічного фактора ураження ПЗ у 90 \% хворих в клінічній картині переважав больовий синдром в епігастральній ділянці: у 90,2 \% жінок, та у 33,5 \% чоловіків. Другим за частотою клінічним проявом був диспепсичний синдром, на який вказали 70 \% обстежуваних.

ДПК знаходиться в тісному взаємозв'язку $з$ оточуючими органами гепатопанкреатодуоденальної зони (ГПДЗ), тому порушення моторноевакуаторної функції (МЕФ) кишки може призвести до розвитку не тільки функціональних, але й органічних уражень органів цієї зони. Клінічні прояви вторинного ураження ПЗ при захворюваннях ДПК і ЖВШ ніби нашаровуються на симптоматику основного захворювання. При цьому функціональних змін ПЗ довгий час може не бути, або вони деякий час залишаються нерозпізнаними. Тому в їх діагностиці велике значення має використання методів для визначення МЕФ верхніх відділів ШКТ, які дають можливість своєчасно не тільки встановити захворювання і функціональні порушення ДПК у хворих на ХП, а й провести диференційну діагностику між первинними та вторинними ураженнями ПЗ. Вивчення саногенезу та обстеження хворих дало можливість встановити наявність виразкової хвороби (ВХ) ДПК у 23 осіб: у 17 (62,9\%) жінок та у 6 (37,1 \%) чоловіків.

Методом поліметрії ми встановили, що вираженість і частота дискінезій ДПК була різною і залежала від стану структури СО. Нормальна моторика ДПК спостерігалась у 21 із 24 хворих з нормальною СО, а також у 9 із 38 хворих з поверхневим неерозивним дуоденітом (ПНЕД) і у 11 із 41 - 3 поверхневим ерозивним дуоденітом (ПЕД). Гіперкінетичний тип виявлений у 14 із 38 хворих з ПНЕД і у 21 із 41 - з ПЕД; гіпокінетичний - у 17 із 38 хворИх з ПНЕД і у 14 із 41 з ПЕД, а також у 12 із 12 з атрофічним неерозивним (АНЕД) і у 7 із 7 хворих з атрофічним ерозивним дуоденітом (АЕД).
О6'єктивну інформацію про моторну діяльність ДПК можна одержати тільки враховуючи періодичний характер їі діяльності з обов'язковим об'єктивним записом і аналізом трьох фаз (I, II і III) циклу міжтравного періоду. При реєстрації МТМ ДПК у обстежених хворих ми спостерігали 3 фази: I - фаза спокою - характеризувалась відсутністю моторної і секреторної активності; II - фаза нерегулярних скорочень - наростанням нерегулярної моторики і секреторної активності; III - фаза регулярної моторики. Для хворих на ХД з атрофією СО, хворих на ХДН і хворих з тяжкими формами ХП характерним був гіпокінетичний тип моторики, причому гіпокінетичний тип з порушенням фазності достовірно частіше $(p<0,05)$ зустрічався у хворих 3 декомпенсованою ХДН. Для ерозивного дуоденіту і виразкової хвороби ДПК характерний гіперкінетичний тип моторики. Виявлена чітка залежність порушення фазної моторики від стадії захворювання, форми і тяжкості перебігу. Так, в стадіях суб- і декомпенсації у хворих на ХДН третя фаза ритмічних скорочень була відсутня в $(53 \pm 10) \%$ випадків, тоді як у хворих з ХД - лише у $(8 \pm 3) \%$ $(P<0,05)$. При гіпомоторній дискінезії подовжувалась I фаза, тривалість якої коливалась від 42 до 72 хвилин (при нормі $(25,1 \pm 5,0))$. Базальний тиск у ДПК в половині випадків був помірно підвищеним і складав від 50 до 120 мм водного стовпчика. Фаза нерегулярних скорочень була більш тривалою, ніж в нормі $(\mathrm{P}<0,01)$, і в середньому складала $(91,3 \pm 4,2)$ хв. Характерною особливістю гіпокінетичного типу моторики було зниження амплітуди скорочень у половини хворих. Частота скорочень була $(1,0 \pm 0,1)$ і варіювала від 0,6 до 1,44 хвилини. Ритмічна фаза складала в середньому $(4,0 \pm 0,9)$ скорочень і коливалась від 3,0 до 5,5 хвилини. Висота скорочень була меншою, ніж у нормі, і складала $(152,2 \pm 30,2)$ мм водного стовпчика. У $29 \%$ хворих ритмічна фаза при тривалій реєстрації запису (більше двох годин) отримана не була.

У хворих з дуоденостазом реєструвалося подовження I I II фаз моторики, а в ряді випадків і відсутність III фази. Базальний тиск у ДПК був значно знижений, наближався до атмосферного і складав в середньому $(62,2 \pm 24,6)$ мм водного стовпчика.

Гіперкінетичний тип моторики ДПК характеризувався скороченням фази спокою і нерегулярної моторики $(P<0,01)$, подовженням ритмічної фази, частотою і зростанням кишкових скорочень. Фаза спокою становила в середньому $(16,0 \pm$ $2,9)$ хвилин. Базальний тиск в ДПК був підвищеним і в середньому дорівнював $(160,2 \pm 22,3)$ мм водного стовпчика. Фаза нерегулярної моторики продовжувалась менше 50 хвилин. Ритмічна фаза в середньому була $(8,0 \pm 1,5)$ хвилин, недостовірно більша ніж в нормі $(P>0,05)$. 
Огляди літератури, оригінальні дослідження, погляд на проблему

Метод поліметрії дозволив одночасно визначити і рН шлунка в залежності від характеру структури СО АВШ і ДПК. Показник базального антрального рН при нормальній СО АВШ в середньому був $(4,5 \pm 0,5)$, тобто виявив кисле середовище. При поверхневому антральному гастриті базальний рН в середньому був $(5,0 \pm 0,3)$, при ерозивному - $(1,9 \pm 0,4)$ і при атрофічному - $(6,5 \pm 0,2)$.

Проведене дослідження доводить, що одночасне визначення моторики ДПК, тиску в її отворі і рН шлунка $\epsilon$ точним, надійним і ефективним засобом вивчення функціонального стану ДПК і органів, які її оточують. Метод поліметрії в даному випадку є найоптимальнішим.

Вивчення тонічної і функціональної активності ПЗ в МТП за допомогою ультрасонографії в режимі моніторингу показало, що її розміри і ехоструктура непостійні як у хворих, так і у здорових. Вони змінюються залежно від фаз МТМ ДПК. Проте, на відміну від здорових, у яких залоза буває найбільшою в II фазу, нерегулярної моторики, а найменшою - в III, фазу ритмічних скорочень - коливання змін розмірів і структури у хворих залежать від тяжкості перебігу і тривалості основного

\section{ЛІТЕРАТУРА}

1. Бондаренко О. А. Клинические особенности хронического панкреатита, протекающего на фоне ожирения / О. А. Бондаренко // Вестн.клуба панкреатол. - 2011. - № 3 (12). - С. 31-33.

2. Гонцарюк Д. А. Хронический панкреатит в сочетании с ожирением, метаболическим синдромом: возможные общие механизмы развития / Д. А. Гонцарюк, Т.Н.Христич, Я.М.Телеки//Сучасна гастроентерологія. 2016. - № 1 (87). - С. 123-128.

3. Коцаба Ю. Я. Комплексна корекція ентеропанкреативного синдрому при хронічному панкреатиті в практиці сімейного лікаря / Ю. Я. Коцаба, Л. С. Бабінець, О. В. Денефіль // Всеукраїнський науково-практичний журнал «Сімецйна медицина». - 2013. - № 5. - С. 79-80.

4. Ткач С. М. Практические подходы к диагностике хронического панкреатита / С. М. Ткач // Сучас. гастроентерол. - 2013. - № 1. - С. 136-141.

\section{REFERENCES}

1. Bondarenko, O.A. (2011). Klinicheskiye osobennosti khronicheskogo pankreatita, protekayushchego na fone ozhireniya [Clinical features of chronic pancreatitis, which is accompanied by obesity]. Vestn. kluba pankreatol. - Journal of Pancreatology Club, 3 (12), 31-33 [in Russian].

2. Gontsaryuk, D.A., Khristich, T.N., \& Teleki, Ya.M. (2016). Khronicheskiy pankreatit v sochetanii s ozhireniyem, metabolicheskim sindromom: vozmozhnyye obshchiye mekhanizmy razvitiya [Chronic pancreatitis in combination with obesity, metabolic syndrome: possible common me- захворювання, а також від типу дискінезії ДПК. При гіпомоторній дискінезії, характерній для АД і ХПДП, вираженої динаміки в змінах розмірів і ехоструктури ПЗ нами не виявлено $(P>0,05)$. Для хворих на ХД і ВХДПК з гіперкінетичним типом моторики ДПК характерним було зменшення розмірів ПЗ і підсилення їі ехоструктури в II i III фази моторики (Р<0,05ХП). У хворих на ХП, частіше із тривалістю захворювання більше 15 років і при важкому перебігу, коливання змін розмірів і ехоструктури ПЗ за фазами МТМ не виявлялись $(\mathrm{P}<0,05)$. Дані ультрасонографії в динаміці відповідали формі і стадії ХП.

Висновки. 1. Показники фазної тонічної активності ПЗ в МТП є важливими критеріями в диференційній діагностиці органічних уражень ПЗ, зокрема при ХП, і функціонального її стану, відповідно до фаз моторики і типу дискінезії ДПК.

2. Для одержання об'єктивної інформації про стан підшлункової залози при ультрасонографії слід враховувати тривалість МТП (в середньому 90 хвилин), фазні зміни розмірів і ехоструктури П3, і проводити дослідження тричі з інтервалом не менше 30 хвилин.

5. Циммерман Я. С. Хронический панкреатит: современное состояние проблемы // Клиническая медицина. - 2007. - № 2. - С. 9-14.

6. Шеховцова Ю. А. Особенности клинических проявлений хронического панкреатита у больных сахарным диабетом 2 типа в сочетании с ожирением // Сучасна гастроентерологія. - 2014. - № 5 (79). - С. 81-86.

7. Epidemiology of chronic pancreatitis burden of the disease and conseguences / P. Levy, E. Dominguez-Munoz, C. Imrie [et al.] // Un. Eur. Gastroenterol. J. - 2014. - No. 2. P. 345-354

8. Zhuan Liao. Guidelines: diagnosis and therapy for chronic pancreatitis / Zhuan Liao, Jn. Gang // J. Gastroenterol. - 2013. - No. 3 (4). - P. 133-136.

chanisms of development]. Suchasna gastroyenterolohíia Modern Gastroenterology, 1 (87), 123-128 [in Russian].

3. Kotsaba, Yu.Ya., Babínets, L.S., \& Denefil, O.V. (2013). Kompleksna korektsiia enteropankreatynoho syndromu pry khronichnomu pankreatyti v praktytsi simeinoho likaria [Integrated correction of enteropancreatic syndrome in chronic pancreatitis in the practice of a family doctor]. Vseukrainskyi naukovo-praktychnyi zhurnal "Simeina medytsyna" All-Ukrainian Scientific and Practical Journal Family Medicine, 5, 79-80 [in Ukrainian]. 
Огляди літератури, оригінальні дослідження, погляд на проблему

4. Tkach, S.M. (2013). Prakticheskie podkhody k diagnostike khronicheskogo pankreatita [Practical approaches to the diagnosis of chronic pancreatitis]. Suchas. hastroenterol. - Modern Gastroenterology, (1), 136-141 [in Russian].

5. Tsimmerman, Ya.S. (2007). Khronicheskiy pankreatit: sovremennoye sostoyaniye problemy [Chronic pancreatitis: the current state of the problem]. Klinicheskaya meditsina - Clinical Medicine, (2), 9-14 [in Russian].

6. Shekhovtsova, Yu.A. (2014). Osobennosti klinicheskikh poyavleniy khronicheskogo pankreatita u bolnykh

sakharnym diabetom 2 tipa v sochetanii s ozhireniyem [Features of clinical manifestations of chronic pancreatitis in patients with type 2 diabetes combined with obesity]. Suchasna hastroyenterolohiia - Modern Gastroenterology, 5 (79), 81-86.

7. Levy, P., Dominguez-Munoz, E, \& Imrie, C. (2014). Epidemiology of chronic pancreatitis burden of the disease and conseguences. Un. Eur. Gastroenterol. J., (2), 345-354

8. Zhuan Liao, \& Gang Jn. T Guidelines: diagnosis and therapy for chronic pancreatitis. J. Gastroenterol., 3 (4), 133-136.

\title{
ДИАГНОСТИКА ХРОНИЧЕСКОГО ПАНКРЕАТИТА И ФУНКЦИОНАЛЬНЫХ НАРУШЕНИЙ ПОДЖЕЛУДОЧНОЙ ЖЕЛЕЗЫ ПРИ ЗАБОЛЕВАНИЯХ ДВЕНАДЦАТИПЕРСТНОЙ КИШКИ
}

\section{๑Л. Ф. Кузнецова, Ю. И. Решетилов, С. Н. Дмитриева, Т. В. Богослав, Н. Н. Проценко,} Е. Ю. Васильченко, М. В. Бондарь, А. А. Партеса

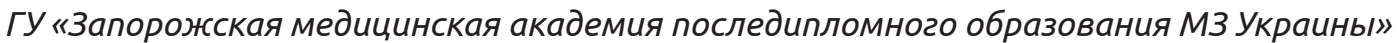 \\ Запорожский государственный медицинский университет
}

РЕзЮМЕ. В работе представлены результаты исследования тонической и функциональной активности поджелудочной железы (ПЖ) в межпищеварительный период (МПП) у больных хроническим панкреатитом (ХП) при сопутствующей патологии двенадцатиперстной кишки (ДПК).

Цель - определить состояние ПЖ в МПП у больных ХП при заболеваниях ДПК с использованием метода полиметрии и ультрасонографии в режиме мониторинга.

Результаты. Исследование по указанной методике показало, что размеры и эхоструктура Пж не постоянны как у больных, так и у здоровых. Они изменяются в зависимости от фаз МПП ДПК. У здоровых железа бывает наибольшей во II фазу нерегулярной моторики, длящуюся $(56,8 \pm 4,1)$ минут, а в III фазу ритмических сокращений, длящуюся $(7,6 \pm 0,8)$ минут - она бывает наименшей, а эхоструктура ее при этом повышается. Колебания размеров Пж относительно фаз МПМ в среднем составляют: в области головки - $(3,0 \pm 0,1)$ мм, в области тела - $(6,0 \pm 0,4)$ мм и в области хвоста - $(7,0 \pm 0,2)$ мм. У больных ХП колебания размеров и ехоструктуры железы зависят от тяжести и длительности основного заболевания, а также от типа сопутствующей дискинезии ДПК. При гипомоторной дискинезии, характерной для АД и ХНДП, выраженной динамики в изменениях размеров железы и эхоструктуры мы не наблюдали $(P<0,05)$. У больных ХД и гипермоторной дискинезией ДПК виявлено уменьшение размеров Пж и повышение ее эхоструктуры во II и в III фазах моторики $(P<0,05)$. У больных же ХП, особенно при тяжелом течении и длительности заболевания более 15 лет, изменений размеров и эхоструктуры в соответствии с фазами МПМ не выявилось $(P<0,05)$. Данные ультрасонографии ПЖ в динамике у этих больных соответствовали форме и стадии ХП.

Использование указанной методики в нашем исследовании позволило лишь у 29,0% обследованых больных выявить ХП, подтвердив его наличие клиническими, лабораторными, инструментальными исследованиями, у остальных 71,0 \%, направленных в клинику с диагнозом ХП, изменения со стороны ПЖ рассматривать как функциональные, вторичные, клинически соответствующие гипо- или гипермоторной дискинезии ДПК.

Выводы. 1. Показатели фазной тонической активности ПЖ в МПП являються важными критериями в дифференциальной диагностике органических поражений, в частности при ХП, и функционального ее состояния, соответствующего фазам моторики и типу дискинезии ДПК.

2. Для получения объективной информации о состоянии Пж при УзИ необходимо учитывать длительность МПП (в среднем 90 минут), фазные изменения размеров и эхоструктуры железы и проводить исследование трижды с интервалом минимум 30 минут.

КЛючЕВЫЕ СЛОВА: поджелудочная железа; хронический панкреатит; двенадцатиперстная кишка; фазы моторики; межпищеварительный период. 


\title{
Огляди літератури, оригінальні дослідження, погляд на проблему \\ DIAGNOSIS OF CHRONIC PANCREATITIS AND FUNCTIONAL DISORDERS OF THE PANCREAS IN DISEASES OF THE DUODENUM
}

\author{
@L. P. Kuznetsova, Yu. I. Reshetilov, S. M. Dmitrieva, T. V. Bogoslav, N. M. Protsenko, \\ O. Yu. Vasilchenko, M. V. Bondar, A. A. Partesa \\ Zaporizhzhia Medical Academy of Postgraduate Education \\ Zaporizhzhia State Medical University
}

SUMMARY. The paper presents the results of the investigation of the tonic and functional activity of the pancreas in the inter-digestive period (IDP) in patients with chronic pancreatitis (CP) with concomitant duodenal pathology (CDP).

The aim - to determine the condition of the prostate in IDP in patients with HP in cases of CDP with the use of the method of polymorphism and ultrasonography in the monitoring mode.

Results. A study using this technique showed that the size and echostructure of the prostate is not constant in patients, as in healthy patients. They vary depending on the phases of the IDP duodenum. In healthy glands, there is the greatest in the II phase of irregular motor, lasting $(56.8 \pm 4.1)$ minutes, and in the III phase of rhythmic contractions, lasting $(7.6 \pm 0.8)$ minutes - it is the lowest, and its echost structure, at the same time, it increases. The fluctuations in the size of the pancreas relative to the IDP phases, on average, are: in the head region $(3.0 \pm 0.1) \mathrm{mm}$, in the body region $-(6.0 \pm 0.4)$

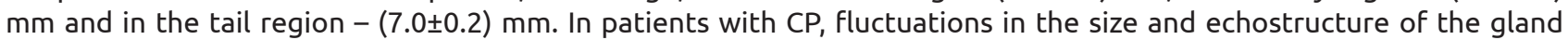
depend on the severity and duration of the underlying disease, as well as the type of concomitant dyskinesia of the duodenum. When hypomotor dyskinesia, characteristic of AD and chronic disturbance of duodenal patency, we did not observe pronounced dynamics in changes in the size of the gland and echostructure $(P<0.05)$. In patients with $C D$ and hypermotor dyskinesia of the duodenum, a decrease in the size of the pancreas and an increase in its echostructure in the II and in the III phase of motility $(\mathrm{P}<0.05)$ is revealed. In patients with HP, especially with severe course and duration of the disease, more than 15 years, changes in size and echostructure in accordance with the phases of IDP - was not detected $(P<0.05)$. The data of ultrasonography of the prostate in the dynamics in these patients corresponded to the form and stage of CP.

The use of this technique in our study allowed only $29.0 \%$ of the examined patients to identify CP, confirming its presence with clinical, laboratory instrumental studies, in the remaining $71.0 \%$ sent to a clinic with a diagnosis of CP, changes from the prostate are considered functional, secondary, clinically relevant hypo- or hypermotor dyskinesia duodenum.

Conclusions. 1. Indicators of the phase tonic activity of the prostate in IDP - are important criteria in the differential diagnosis of organic lesions, in particular in $\mathrm{CP}$, and its functional state, corresponding to motor phases and the type of dyskinesia of the duodenum.

2. To obtain objective information about the condition of the pancreas in ultrasound, it is necessary to take into account the duration of IDP (in nonsensical 90 minutes), the phase changes in the size and echostructure of the gland and to conduct the study three times with an interval of at least 30 minutes.

KEY WORDS: pancreas; chronic pancreatitis; duodenum; motor phases; inter-digestive period.

Отримано 12.07.2017 